\title{
Differential white blood cell counts in apparently healthy Eritrean blood donors at the National Blood Transfusion Center, Asmara, Eritrea
}

\author{
Faris M. Abdon ${ }^{1}$, Elias T. Adgoy ${ }^{1}$, Nahom Y. Berhane ${ }^{2}$, Senet A. Ibrahim² ${ }^{2}$, Adil K. H. Khalil ${ }^{3}$, Yemane Seyoum ${ }^{1}$, Osama S. Abbadi ${ }^{4}$
}

\author{
AFFILIATION \\ 1 Orotta College of Medicine and Health Sciences, Asmara, Eritrea \\ 2 National Blood Transfusion Service, Asmara, Eritrea \\ 3 College of Medicine, Dar Al Uloom University, Riyadh, Kingdom of Saudi \\ Arabia \\ 4 Omdurman Islamic University, Omdurman, Sudan
}

\section{CORRESPONDENCE TO}

Osama S. Abbadi. Omdurman Islamic University, Omdurman, Sudan. E-mail: aslikhalis@yahoo.com ORCID ID: https://orcid.org/0000-0003-1583-5871

Popul. Med. 2020;2(April):8
KEYWORDS

lymphocytes, blood donors, white blood cells, granulocytes

Received: 4 March 2020, Revised: 12 March 2020,

Accepted: 4 April 2020

\begin{abstract}
INTRODUCTION To our knowledge, no study has been conducted on white blood cell counts in healthy Eritrean blood donors. Therefore, this study will help to establish the reference ranges of white blood cell (WBC) counts in Eritrean people and to correlate them with the participant's age and gender, and give measures of the differential neutrophils, eosinophils, basophils, monocytes, and lymphocytes numbers and concentrations in healthy blood donors attending the national blood bank of Eritrea.

METHODS A total of 610 voluntary non-remunerated blood donors between the ages of 16 and 65 years were recruited for the study. Blood samples were collected into an EDTAtube and examined for total white blood cell (TWBC)
\end{abstract}

https://doi.org/10.18332/popmed/120071 count and differential white blood cell counts (neutrophils, lymphocytes, eosinophils, monocytes, and basophiles). Results were statistically analyzed by the Microsoft Excel program.

RESULTS The overall mean TWBC count was $5.774 \pm 2.013$ $\left(\times 10^{9} / \mathrm{L}\right)$, the difference between the male and female means was significant, as was also the difference between male and female neutrophil count, with higher values for female donors.

CONCLUSIONS The total and differential counts of white blood cells in the Eritrean healthy blood donors were all within global reference ranges, with significant differences in total and neutrophil counts between males and females.

\section{INTRODUCTION}

White blood cells (WBCs), also known as leukocytes, are the cell lineage responsible of counteracting infections in the body ${ }^{1,2}$. These cells are synthesized in the bone marrow. They are classified according to the presence of characteristic intracellular granules into granulocytes that are further subclassified into neutrophils, eosinophils and basophils ${ }^{3}$. The other types of cells are the agranulocytes that are of four main types: monocytes, macrophages, t-lymphocytes, and b-lymphocytes ${ }^{3}$. Different types of WBCs serve different functions, and, accordingly, their number and distribution in the body fluctuate, however there are specific reference ranges for the total number of WBCs as well as a specific percentage of each type of cell lineage. The normal reference value of total white blood cell (TWBC) count differs according to the age of the individual. A range of $9.000-30.000\left(\times 10^{9} / \mathrm{L}\right)$ is standard at birth, but it decreases slowly through childhood and adolescence to settle at $4.000-11.000\left(\times 10^{9} / \mathrm{L}\right)$ for a healthy adult $^{4}$, while the count of each cell type is considered normal as follows: neutrophils 2.000-7.500 $\left(\times 10^{9} / \mathrm{L}\right)$, eosinophils $<0.45\left(\times 10^{9} / \mathrm{L}\right)$, basophils $<0.1\left(\times 10^{9} / \mathrm{L}\right)$, monocytes $0.2-0.8$ $\left(\times 10^{9} / \mathrm{L}\right)$, and lymphocytes $1.500-3.500\left(\times 10^{9} / \mathrm{L}\right)^{5}$. These ranges could change according to microbial threats. Other than the response to infection, the white blood cells (WBCs) can be affected by age, sex, and body mass index (BMI). There are studies that document a higher white blood cell count in obese people compared to the non-obese ${ }^{6}$. A study by Taha et al. ${ }^{7}$ indicated that there is no significant difference between 
males and females but a significant difference in age and BMI in the WBC count ${ }^{7}$. White blood cell count is commonly and routinely used as a clinical diagnostic measure to detect different disease conditions. Those who are selected for blood donation should be from a population group with low risk of infection or prevalence of infectious diseases. All blood donors are asked about their medical history to help determine if they can safely donate blood without experiencing any negative health effects ${ }^{8}$. Many studies revealed that there is a significant difference in the haematological reference ranges by sex and body weight and height (BMI) index. Considerable differences in haematological values between western and African people are also observed ${ }^{9}$. To our knowledge, no study has been conducted on the white blood cell count in apparently healthy Eritrean blood donors. Therefore, this study will help to establish the reference ranges of white blood cell count in Eritrean people and to correlate them with the participant's age and gender.

\section{METHODS}

\section{Study design and study area}

This was a descriptive cross-sectional study conducted in the National Blood Transfusion Center, Eritrea, from 1 April to 30 June 2019. The National Blood Bank is the only blood bank in the country that is situated around the National Referral Hospitals of the country.

\section{Study participants}

All voluntary donors during the study period were selected according to the accepted criteria for blood donation that include: age, weight, physical and medical examination, screening for viral infections (hepatitis B, C and HIV) and test for syphilis and non-communicable diseases (diabetes, hypertension etc.). Setting a confidence level of $95 \%$, and confidence interval 4.0 , and previously knowing that the population of Eritrea is 3.2 million (2010 census), the calculated sample size was 601 participants. Therefore, a total of 610 voluntary non-remunerated blood donors, 205 females and 405 males, between the ages of 16 and 65 years consented to participate in the study.

\section{Data collection method}

\section{Questionnaire}

A standard donor questionnaire, designed by ENBTS for counselling purposes, was used to collect information like demographic data, current health status, medical status, medical history and social habits of each blood donor.

\section{Laboratory investigations}

Blood samples were obtained from the blood donors during blood donation activities of the National Blood Transfusion Service (NBTS). Blood sampling was performed by trained staff working in ENBTS following a standard operating procedure for blood sample collection. A sample of $4 \mathrm{~mL}$ of venous blood was collected into a K3EDTA-tube (Becton Dickinson, Plymouth, UK) and a sample of $6 \mathrm{~mL}$ venous blood was collected into a serum tube from the participants. Blood samples collected into the EDTA-tube were examined for total white blood cell (TWBC) count and differential white blood cell counts (neutrophils, lymphocytes, eosinophils, monocytes, and basophiles). The $6 \mathrm{~mL}$ venous blood collected was analyzed by cobas-e 411 for the screening of HIV, hepatitis $B$ virus surface antigen (HbsAg), hepatitis $\mathrm{C}$ virus antibodies (HcAbs), and syphilis. Both instruments participate in an external quality assurance program and routine internal quality control product was run before analyzing each sample.

\section{Data analysis}

Data analysis was done using Microsoft Excel 2007 data sheet, and SPSS version 22 . The descriptive analytical data and tests of statistical significance were performed using the two-sample t-test (assuming equal variances) for the difference between males and females. Pearson's correlation assessment was also performed by Excel 2007 for both age and weight of the participants.

\section{RESULTS}

The overall mean TWBC count was $5.774 \pm 2.013\left(\times 10^{9} / \mathrm{L}\right)$, with a range $2.3-16.36\left(\times 10^{9} / \mathrm{L}\right)$. The median TWBC count was $5.410\left(\times 10^{9} / \mathrm{L}\right)$ and the mode was $3.510\left(\times 10^{9} / \mathrm{L}\right)$. The range of values at the $95 \%$ confidence level was $1.750-9.800\left(\times 10^{9} / \mathrm{L}\right)$. There were eight readings of TWBC count above $11.000\left(\times 10^{9} / \mathrm{L}\right)$, representing $0.13 \%$ of the sample size, and 57 readings of TWBC count below 3500 $\left(\times 10^{9} / \mathrm{L}\right)$, representing $0.93 \%$ of the sample size. Mean TWBC count for males was $5.494\left(\times 10^{9} / \mathrm{L}\right)$ and for females $6.321\left(\times 10^{9} / \mathrm{L}\right)$, with the difference between the two means significant. Also, the difference between the male and female neutrophil count was significant: $2.670\left(\times 10^{9} / \mathrm{L}\right)(48.6 \%$ of TWBC count) and $3.370\left(\times 10^{9} / \mathrm{L}\right)(58.54 \%$ of TWBC count), respectively. The differences between males and females in eosinophil, basophil, monocyte and lymphocyte counts and percentages were all insignificant. Table 1 summarizes the important results of TWBC and differential WBC counts and concentrations. The correlations of age and weight of the

Table 1. TWBC and detailed WBC counts (n) and concentrations (\%), according to sex, among healthy blood donors attending the national blood bank of Eritrea $(\mathrm{N}=650)$

\begin{tabular}{|l|c|c|c|c|c|c|} 
Parameter & TWBCs & $\begin{array}{c}\text { Neutrophils } \\
\text { n (\%) }\end{array}$ & $\begin{array}{c}\text { Eosinophils } \\
\text { n (\%) }\end{array}$ & $\begin{array}{c}\text { Basophils } \\
\text { n (\%) }\end{array}$ & $\begin{array}{c}\text { Monocytes } \\
\text { n (\%) }\end{array}$ & $\begin{array}{c}\text { Lymphocytes } \\
\text { n (\%) }\end{array}$ \\
\hline Total $\left(\times 10^{9} / \mathrm{L}\right)$ & 5.774 & $2.91(48.52)$ & $0.595(9.83)$ & $0.0192(0.36)$ & $0.436(7.9)$ & $1.815(33.39)$
\end{tabular}


Table 1. Continued

\begin{tabular}{l|c|l|l|l|l|l|} 
Parameter & \multicolumn{1}{|c|}{$\begin{array}{c}\text { TWBCs } \\
\mathbf{n}\end{array}$} & $\begin{array}{c}\text { Neutrophils } \\
\mathbf{n}(\%)\end{array}$ & $\begin{array}{c}\text { Eosinophils } \\
\mathbf{n}(\%)\end{array}$ & $\begin{array}{c}\text { Basophils } \\
\mathbf{n}(\%)\end{array}$ & $\begin{array}{c}\text { Monocytes } \\
\text { n (\%) }\end{array}$ & $\begin{array}{c}\text { Lymphocytes } \\
\text { n (\%) }\end{array}$ \\
\hline Males $\left(\times 10^{9} / \mathrm{L}\right)$ & 5.494 & $2.67(48.6)$ & $0.579(10.54)$ & $0.0191(0.35)$ & $0.434(7.87)$ & $1.789(32.56)$ \\
Females $\left(\times 10^{9} / \mathrm{L}\right)$ & 6.321 & $3.37(58.54)$ & $0.627(9.92)$ & $0.0194(0.35)$ & $0.442195(7.0)$ & $1.867707(29.55)$ \\
Calculated t-test* & 4.890246 & 5.774043 & 0.829456 & 0.411391 & 0.836815 & 1.867858 \\
Critical t-test & 1.963873 & 1.963873 & 1.963873 & 1.963873 & 1.963873 & 1.963873 \\
p-value & $<0.001$ & $<0.001$ & 0.407172 & 0.680931 & 0.403025 & 0.062263
\end{tabular}

*Paired t-test with the assumption of equal variance was used; hence the calculated t-value is compared with the critical t-value to assess significance.

Table 2. Pearson's correlations between age and weight and WBC measures among healthy blood donors attending the national blood bank of Eritrea $(\mathrm{N}=650)$

$\begin{array}{lccccccc}\text { Parameter } & \text { TWBCs } & \text { Neutrophils } & \text { Eosinophils } & \text { Basophils } & \text { Monocytes } & \text { Lymphocytes } \\ \begin{array}{l}\text { Age correlation } \\ \text { coefficient }\end{array} & -0.14169 & -0.11744 & -0.02335 & -0.01639 & -0.11714 & -0.17234 \\ & * & * & * & * & * & * \\ \begin{array}{l}\text { Weight correlation } \\ \text { coefficient }\end{array} & -0.04354 & -0.07474 & 0.07713 & 0.007368 & 0.010688 & -0.06795 \\ & * & * & * * & * * & * & * \\ \text { * } & & & & & \end{array}$

donors and the WBC differentials in this study were very weak, with only very weak possible positive correlations between the weight of the donor and the eosinophils, basophils and monocytes (Table 2).

\section{DISCUSSION}

The result of overall mean TWBC count for the chosen sample was within the normal reference ranges of hematological reference books. The difference between the male and female mean values was significant. Neutrophil count difference between genders was significant, but the difference in means for eosinophils, basophils, monocytes and lymphocytes was not statistically significant. The correlations between the weight and age of the participants and the readings were all weak or very weak. Since the $95 \%$ confidence gives each tail of the data within a $2.5 \%$ margin, the sample is representative of the global reference range. According to a similar study conducted on apparently healthy male donors in Sudan (west of Eritrea) by Abbas et al. ${ }^{2}$, the $95 \%$ confidence interval slightly deviates from the global reference range ${ }^{2}$. Detailed results are given in Table 3 from the present study for Eritrea and from another study for Eritrea ${ }^{10}$, together with results for Sudan ${ }^{2}$, Ethiopia ${ }^{11}$ and values from the reference book of Dacie and Lewis ${ }^{5}$,

Table 3. Comparisons between the current study, a haematology reference, and similar studies from Sudan, Eritrea and Ethiopia.

\begin{tabular}{|c|c|c|c|c|c|}
\hline Parameter & $\begin{array}{l}\text { Dacie \& Lewis } \\
\text { (Book) }\end{array}$ & $\begin{array}{l}\text { Sudan } \\
(2015)\end{array}$ & $\begin{array}{l}\text { Ethiopia } \\
\text { (2016) }\end{array}$ & $\begin{array}{l}\text { Eritrea } \\
(2018)\end{array}$ & $\begin{array}{l}\text { Current study } \\
\text { (Eritrea 2019) }\end{array}$ \\
\hline \multicolumn{6}{|c|}{ TWBCs $\left(\times 10^{9} / \mathrm{L}\right)$} \\
\hline Males & & & $\begin{array}{l}\text { Median } \\
5.900\end{array}$ & $\begin{array}{l}\text { Mean } \\
5.900\end{array}$ & $\begin{array}{l}\text { Mean } \\
5.494\end{array}$ \\
\hline \multicolumn{6}{|l|}{ Females } \\
\hline & & & $\begin{array}{l}\text { Media } \\
5.900\end{array}$ & $\begin{array}{l}\text { Mean } \\
5.800\end{array}$ & $\begin{array}{l}\text { Mean } \\
6.321\end{array}$ \\
\hline \multicolumn{6}{|l|}{ Total } \\
\hline & $4.000-11.000$ & $\begin{array}{l}\text { Mean } \\
5.640\end{array}$ & & $\begin{array}{l}\text { Mean } \\
5.600\end{array}$ & $\begin{array}{l}\text { Mean } \\
5.774\end{array}$ \\
\hline
\end{tabular}


Table 3. Continued

\begin{tabular}{|c|c|c|c|c|c|}
\hline Parameter & $\begin{array}{c}\text { Dacie \& Lewis } \\
\text { (Book) }\end{array}$ & $\begin{array}{l}\text { Sudan } \\
\text { (2015) }\end{array}$ & $\begin{array}{c}\text { Ethiopia } \\
\text { (2016) }\end{array}$ & $\begin{array}{l}\text { Eritrea } \\
(2018)\end{array}$ & $\begin{array}{l}\text { Current study } \\
\text { (Eritrea 2019) }\end{array}$ \\
\hline \multicolumn{6}{|c|}{ Neutrophils (\%) } \\
\hline Males & & & & $\begin{array}{l}\text { Median } \\
53.2\end{array}$ & $\begin{array}{l}\text { Mean } \\
48.6\end{array}$ \\
\hline Females & & & & $\begin{array}{l}\text { Median } \\
55.5\end{array}$ & $\begin{array}{l}\text { Mean } \\
58.54\end{array}$ \\
\hline Total & $\begin{array}{l}2.000-7.500 \\
\left(\times 10^{9} / \mathrm{L}\right)\end{array}$ & $\begin{array}{c}\text { Mean (SD) } \\
54.43(11.58)\end{array}$ & $\begin{array}{c}\text { Mean } \\
53\end{array}$ & $\begin{array}{c}\text { Median } \\
54.7\end{array}$ & $\begin{array}{l}\text { Mean } \\
48.52\end{array}$ \\
\hline \multicolumn{6}{|c|}{ Eosinophils (\%) } \\
\hline Males & & & & & $\begin{array}{l}\text { Mean } \\
10.54\end{array}$ \\
\hline Females & & & & & $\begin{array}{l}\text { Mean } \\
9.92\end{array}$ \\
\hline Total & $\begin{array}{l}<450 / \mathrm{mL} \\
\left(\times 10^{9} / \mathrm{L}\right)\end{array}$ & $\begin{array}{l}\text { Mean (SD) } \\
3.18(2.27)\end{array}$ & $\mathrm{N} / \mathrm{A}$ & & $\begin{array}{l}\text { Mean } \\
9.83\end{array}$ \\
\hline \multicolumn{6}{|c|}{ Basophils (\%) } \\
\hline Males & & & & & $\begin{array}{c}\text { Mean } \\
0.35\end{array}$ \\
\hline Females & & & & & $\begin{array}{c}\text { Mean } \\
0.35\end{array}$ \\
\hline Total & $\begin{array}{l}<100 / \mathrm{mL} \\
\left(\times 10^{9} / \mathrm{L}\right)\end{array}$ & $\begin{array}{l}\text { Mean (SD) } \\
1.22(0.44)\end{array}$ & $\mathrm{N} / \mathrm{A}$ & & $\begin{array}{l}\text { Mean } \\
0.36\end{array}$ \\
\hline \multicolumn{6}{|c|}{ Monocytes (\%) } \\
\hline Males & & & & $\begin{array}{l}\text { Median } \\
7.6\end{array}$ & $\begin{array}{l}\text { Mean } \\
7.87\end{array}$ \\
\hline Females & & & & $\begin{array}{l}\text { Median } \\
7.6\end{array}$ & $\begin{array}{l}\text { Mean } \\
7.0\end{array}$ \\
\hline Total & $\begin{array}{l}200-800 \\
\left(\times 10^{9} / \mathrm{L}\right)\end{array}$ & $\begin{array}{l}\text { Mean (SD) } \\
2.07(1.5)\end{array}$ & & $\begin{array}{l}\text { Median } \\
7.6\end{array}$ & $\begin{array}{l}\text { Mean } \\
7.9\end{array}$ \\
\hline \multicolumn{6}{|c|}{ Lymphocytes (\%) } \\
\hline Males & & & & $\begin{array}{l}\text { Median } \\
38.7\end{array}$ & $\begin{array}{l}\text { Mean } \\
32.56\end{array}$ \\
\hline Females & & & & $\begin{array}{l}\text { Median } \\
36.5\end{array}$ & $\begin{array}{l}\text { Mean } \\
29.55\end{array}$ \\
\hline Total & $\begin{array}{c}1.500-3.500 \\
\left(\times 10^{9} / \mathrm{L}\right)\end{array}$ & $\begin{array}{l}\text { Mean (SD) } \\
41.2(11.5)\end{array}$ & $\begin{array}{c}\text { Mean } \\
37\end{array}$ & $\begin{array}{l}\text { Median } \\
37.3\end{array}$ & $\begin{array}{l}\text { Mean } \\
33.39\end{array}$ \\
\hline Comments & General mean & Male donors only & EBM $10 \%$ & - & - \\
\hline References & {$[5]$} & [2] & {$[11]$} & [10] & $\mathrm{N} / \mathrm{A}$ \\
\hline
\end{tabular}

N/A: Not available. EBM: Eosinophils + Basophils + Monocytes. SD: standard deviation.

for comparison. We note that while the TWBC counts are similar in all the studies, the granulocytes, monocytes and lymphocytes percentages differ considerably between the Sudan 2015, Eritrea 2018 and current Eritrea study. This could be attributed to the different environments of the countries, as granulocyte expression is related to the presence of specific bacterial populations (neutrophils) and parasites (basophils) in addition to the allergens surrounding humans (eosinophils).

\section{Strengths and limitations}

The current study has the advantage of having a suitable representative sample size with a wide age spectrum, for both genders. There was proper screening for blood 
transmitted infection, and also highly trained staff were recruited for sampling and processing the results. Other advantages of this study are the choice of a homogenous sample (healthy blood donors) and the comparison of the results (Table 3) with other healthy blood donors studies in the Horn of Africa. The major limitation of this study is that it did not take into consideration the different ethnic and geographical parameters of all the Eritrean population. It is recommended that a biological reference library for citizens of Eritrea and other East African countries is established, carefully taking into account ethnic diversity, nutritional status and age.

\section{CONCLUSIONS}

This was a descriptive cross-sectional study performed in the National Blood Bank in Asmara where WBC levels and differential leucocyte counts were measured for 610 healthy blood donors. The results were found to be within reference normal ranges. The TWBC count was found to be significantly higher in females. Correlations between the results with age and weight were found not to be significant.

\section{REFERENCES}

1. Wiseman BK. The origin of white blood cells. JAMA. 1934;103(20):1524-1529. doi:10.1001/ jama.1934.02750460028008

2. Abbas AA, Khalil AKH, Yasir H, Fadlallah S, Huwaida O. White Blood Counts In Apparently Healthy Sudanese Blood Donors in Gezira State (Sudan). PYRX J Bio Res. 2015;1(6):86-90. https://www.pyrexjournals.org/pjbr/pdf/2015/december/ abbas.pdf. Accessed March 4, 2020.

3. Amador E. Health and normality. JAMA. 1975;232:953-955. doi:10.1001/jama.1975.03250090 041018

4. Gordon-Smith T. Structure and function of red and white blood cells. Medicine. 2013;41(4):193-199. doi:10.1016/j.mpmed.2009.01.013

5. Dacie JV, Lewis SM. Practical Haematology. 10th ed. London, UK: Churchill Livingstone; 2006.

6. Urquhart NE, Capildeo KD, Sargeant LA, Wharfe G, Hisada M, Hanchard B. White blood cell counts in healthy Jamaican adults. West Indian Med J. 2008;57(2):147-151. PMID:19565958.

7. Taha EH, Elshiekh M, Alborai A, et al. Normal range of white blood cells and differential count of Sudanese in Khartoum state. Int J Adv Med. 2018;5(4):784-787. doi:10.18203/2349-3933.ijam20183116

8. Dodd RY, Notari EP IV, Stramer SL. Current prevalence and incidence of infectious disease markers and estimated

CONFLICTS OF INTEREST

The authors have completed and submitted the ICMJE Form for Disclosure of Potential Conflicts of Interest and none was reported. window period risk in the American Red cross blood donor population. Transfusion. 2002;42(8):975-979. doi:10.1046/j.1537-2995.2002.00174.x

9. Roshan TM, Rosline H, Ahmed SA, Rapiaah M, Wan Zaidah A, Khattak MN. Hematological reference values of healthy Malaysian population. Int J Lab Hematol. 2009;31(5):505512. doi:10.1111/j.1751-553X.2008.01068.x

10. Siraj N, Issac J, Anwar M, Mehari Y, Russom S, Kahsay S et al. Establishment of hematological reference intervals for healthy adults in Asmara. BMC Res Notes. 2018;11(1):55. doi:10.1186/s13104-018-3142-y

11. Yalew A, Terefe B, Alem M, Enawgaw B. Hematological reference intervals determination in adults at Gondar university hospital, Northwest Ethiopia. BMC Res Notes. 2016;9(1):483. doi:10.1186/s13104-016-2288-8

FUNDING

There was no source of funding for this research. 